\title{
Network Evolution and the Spatiotemporal Dynamics of Knowledge Sourcing
}

\author{
Robert Huggins* \\ School of Planning and Geography \\ Cardiff University \\ Cardiff, UK \\ Tel: +442920876006 \\ Email: hugginsr@cardiff.ac.uk \\ Hiro Izushi \\ Aston Business School \\ Aston University \\ Birmingham, UK \\ Email: h.izushi@aston.ac.uk \\ Daniel Prokop \\ School of Planning and Geography \\ Cardiff University \\ Cardiff, UK \\ Email:prokopd@cardiff.ac.uk \\ Piers Thompson \\ Nottingham Business School \\ Nottingham Trent University \\ Nottingham, UK \\ Email: piers.thompson@ntu.ac.uk
}

*Corresponding author

This is an Accepted Manuscript of an article published by Taylor \& Francis Group in Entrepreneurship \& Regional Development: An International Journal on 5/10/2015, available online: http://www.tandfonline.com/10.1080/08985626.2015.1070538.

To cite this article: Robert Huggins, Hiro Izushi, Daniel Prokop \& Piers Thompson (2015) Network evolution and the spatiotemporal dynamics of knowledge sourcing, Entrepreneurship \& Regional Development, 27:7-8, 474-499, DOI: 10.1080/08985626.2015.1070538 


\title{
Network Evolution and the Spatiotemporal Dynamics of Knowledge Sourcing
}

\begin{abstract}
Knowledge accessing from external organisations is important to firms, especially entrepreneurial ones which often cannot generate internally all the knowledge necessary for innovation. There is, however, a lack of evidence concerning the association between the evolution of firms and the evolution of their networks. The aim of this paper is to begin to fill this gap by undertaking an exploratory analysis of the relationship between the vintage of firms and their knowledge sourcing networks. Drawing on an analysis of firms in the UK, the paper finds some evidence of a U-shaped relationship existing between firm age and the frequency of accessing knowledge from certain sources. Emerging entrepreneurial firms tend to be highly active with regard to accessing knowledge for a range of sources and geographic locations, with the rate of networking dropping somewhat during the period of peak firm growth. For instance, it is found that firms tend to less frequently access knowledge sources such as universities and research institutes in their own region during a stage of peak turnover growth. Overall, the results suggest a complex relationship between the lifecycle of the firm and its networking patterns. It is concluded that policymakers need to become more aware that network formation and utilisation by firms is likely to vary dependent upon their lifecycle position.
\end{abstract}

\section{Introduction}

Knowledge accessing from external organisations is considered to have become increasingly important to entrepreneurial firms, which often cannot generate internally all the knowledge necessary for innovation (Freel, 2000, 2003; Hite and Hesterly, 2001; Yli-Renko, 2001; Almeida et al., 2003; Huggins and Johnston, 2009; Doran et al., 2012). Within an entrepreneurial firm environment, the role of inter-organisational networks and knowledge sources are increasingly recognised as potentially important assets for creating and sustaining innovation and competitiveness (Lechner and Dowling, 2003). There is growing evidence that network development is related to the growth of firms, particularly networks involving the flow of knowledge (Knoben and Oerlemans, 2006).

Emerging theories of the firm such as the knowledge-based view (Grant, 1996) and extensions of the resource-based view (Barney, 1991; Eisenhardt and Schoonhoven, 1996; Lavie, 2006) indicate that the need to access knowledge is a key reason why firms build or enter networks with other organisations. Similarly, others argue that such networks are an asset - namely, network capital, formed through strategic investments in interactions that allow firms access to the knowledge they require to innovate and enhance economic returns (Huggins, 2010; Huggins and Thompson, 2014; Kramera et al., 2011; Kramera and Revilla Diez, 2012; Lawton Smith et al., 2012). These networks concern the relationships and ties 
existing between firms, and may arise through the need to access new technology, skills or expertise in order to keep pace with competitors (Ahuja, 2000; Huggins and Johnston, 2010).

Despite a growing research base, there is still a lack of evidence concerning the evolution of the networks through which firms source and access knowledge to enable innovation. Against this backdrop, the key aim of this paper is to begin to fill this gap by undertaking an exploratory analysis of the relationship between the vintage of firms and their knowledge sourcing networks. This aim chimes with calls for a more dynamic approach to understanding the networks of firms (Hite and Hesterly, 2001; Schutjens and Stam, 2003; Glückler, 2007; Jack et al., 2008, 2010). With this in mind, the paper seeks to address the following questions: (1) to what extent is the frequency of knowledge sourcing associated with the age of firms? (2) to what extent are the types of knowledge sources utilised by firms, and the forms of knowledge accessed, associated with the age of firms? and (3) to what extent is the spatial reach of knowledge sourcing networks associated with the age of firms?

The paper explores knowledge sourcing activities of firms mainly in terms of the types and locations of knowledge sources, as well as the form of the knowledge sourced. Drawing on a range of analysis, the paper suggests that there are a number of associations between the age of firms and the characteristics of their knowledge sourcing networks. In particular, the paper finds some evidence of a U-shaped relationship existing between firm age and the frequency of accessing knowledge from certain sources.

The paper is structured as follows: section 2 outlines the theoretical framework employed to understand the evolution of knowledge sourcing network; section 3 presents the data and methods used for the empirical findings presented in the paper; section 4 provides a presentation of the key findings and results; and section 5 discusses the implications and conclusions arising from the study.

\section{Conceptual Framework}

This section elaborates the broad conceptual framework underpinning the paper. In summary, it seeks to suggest three key arguments related to the knowledge networks generated by firms. First, it is argued that firms form networks with other organisations to obtain access to the knowledge they require to facilitate innovation (subsection 2.1). Second, it is argued that the nature of these networks may evolve as firms evolve, especially as firms move through different phases within their developmental lifecycle and their knowledge needs change (subsection 2.2). Third, it is argued that such networks also have an important spatial 
dynamic relating to the geographic reach of the sources from which they access knowledge (subsection 2.3).

\subsection{Networks, Knowledge and Innovation}

It is generally accepted that the networks underpinning innovation processes allow firms to access knowledge that they do not, or cannot, generate internally based on their own capabilities (Meagher and Rogers, 2004; Lichtenthaler, 2005; Sammarra and Biggiero, 2008; Tomlinson, 2010; Bergenholtz and Waldstrøm, 2011). Knowledge sourcing from external actors has long been acknowledged as a significant factor in successful innovation (Langrish et al., 1972; Rothwell et al., 1974), with innovation increasingly viewed as a systemic undertaking requiring knowledge sourcing between firms and other actors, i.e. firms no longer innovate in isolation but through a complex set of interactions with external actors (Ahuja, 2000; Lechner and Dowling, 2003; Owen-Smith and Powell, 2004; Vanhaverbeke, 2006; Roper et al., 2008). Firms often utilise considerably more knowledge than that which they have themselves created, and the key reason underlying inter-organisational knowledge flows is the search for 'lacking knowledge'(Storper, 2000).

According to Quatraro (2010), knowledge is the outcome of a combinatorial search activity carried out across a technological space in which combinable elements reside. In this sense, the term network covers a wide range of interactions, and, as noted by Contractor and Lorange (2002), may be either horizontal or vertical. Alongside customers, suppliers, and members of professional networks, other potential actors with which firms may engage in innovation related networks include rival firms, private and public sector knowledge providers, and universities. Inter-organisational networks, therefore, can be defined as consisting of the interactions and relationships organisations (principally firms) utilise to access knowledge beyond their market relationships (Huggins et al., 2012). In other words, these networks consist of the means by which knowledge flows across organisations beyond transactions.

Of course, knowledge takes many different forms, with one of the most familiar typologies suggesting that knowledge is either explicit/codified or tacit. In general, explicit knowledge refers to information that can be easily communicated and acted upon among individuals, whereas tacit knowledge - such as skills, competence, and talents - is more difficult to directly communicate to someone else in a verbal or other symbolic form (Nonaka and Takeuchi, 1995; Huggins and Izushi, 2007). Jensen et al. (2007) further suggest that knowledge can be utilised through two key modes through innovation and learning can occur, 
often simultaneously, with the most innovative firms often possessing a capacity to combine both. First, the Science, Technology and Innovation (STI) mode, based on the production and use of codified scientific and technical knowledge; and second the Doing, Using and Interacting (DUI) mode, which relies on informal processes of learning and experience-based know-how. Jensen et al.'s (2007) typology is useful as it makes the connection between the different forms of knowledge and the different modes of its utilisation to foster innovation.

Importantly, the internal capabilities and characteristics of firms, in particular their absorptive capacity, are likely to either facilitate or hinder the effectiveness of their knowledge sourcing activities. Absorptive capacity is often history-dependent and reflects how much a firm invests in the area of expertise it specialises in, and largely depends upon a firm's investment in innovation efforts (Cohen and Levinthal, 1990; Zahra and George, 2002). Good in-house capabilities in $R \& D$, design, engineering and the like help to capture and appropriate knowledge, in both codified and tacit forms, in the process of learning from external sources (Howells, 1996).

\subsection{Firms and the Evolution of Networks}

In general, the search for superior knowledge means there is an increasing focus on the dynamic nature of networks and their changeability, heightening the need for the on-going reconfiguration of networks (Gargiulo and Benassi, 2000; McFadyen and Cannella, 2004; Levine, 2005; Bathelt and Turi, 2011; Huggins, 2011). If firms become increasingly familiar with each other's knowledge, negative effects may emerge, locking firms into low value and unproductive networks and stifling the creation of new knowledge and innovation (Arthur, 1989; Adler and Kwon, 2002; Labianca and Brass, 2006; Broekel and Boschma, 2012). In order to continue to play a role in the innovation process, knowledge networks are often required to evolve to include new members and configurations to meet changing needs (Hite and Hesterly, 2001; Lechner and Dowling, 2003). As Gulati (1999) argues, networks are dynamic and change over time if they are to enhance firm performance, which suggests that firms develop and configure networks so that they can provide access to diverse information and capabilities with minimum costs of redundancy, conflict, and complexity (Oliver, 1997; Baum et al., 2000; Monge and Contractor, 2003).

In order to place the evolution of networks in a context aligned with the evolution of the firm, it is important to consider the particular stages of development firms pass through. Industry life cycle theory contends that firms will generally fit with one of three broad phases - fluid, transitional, and mature - relating to the developmental stage of the industry within 
which they operate (Utterback and Abernathy, 1975; Klepper, 1997; Ter Wal and Boschma, 2011; Balland et al. 2013). Others have pointed to a more specific life cycle of the firm (Agarwal and Gort, 2002), with entrepreneurship researchers suggesting a number of typologies to capture different developmental stages (Larson, 1992; Hite and Hesterly, 2001; Greve and Salaff, 2003; Lechner and Dowling, 2003; Jack et al., 2008; Presutti et al., 2013). Over the potential full life cycle of a firm, these can be summarised as consisting of four broad phases: (1) emergence; (2) growth; (3) maturity; and (4) death.

New entrepreneurial firms at the emergence phase are more likely to be dependent on the interpersonal networks of the entrepreneurs or owners of the firm (e.g., the relatives and friends of the owners) (Thorpe et al., 2005; Anderson et al., 2010). Existing evidence suggests that during the emergence phase entrepreneurs build interpersonal networks where individual ties combine calculative and social aspects (Johannisson et al., 2002; Schutjens and Stam, 2003; Anderson et al., 2007; Anderson et al., 2010). This is to be expected, since for new firms the network requirements of both the firm and the firm's operator (i.e., the entrepreneur) are likely to coincide, and encompass both his/her social and economic needs and objectives (Jack, 2005; Macpherson and Holt, 2007; Jack et al., 2008, 2010).

Studies such as Eisenhardt and Schoonhoven (1996) suggest that networks such as the formation of alliances are a function of both demand and supply factors. In particular, firms in more economically vulnerable situations may have a greater demand for such alliances. On the other hand, the supply of network opportunities is likely to relate to the experience and prestige of the firm. Therefore, both the demand for and supply of network opportunities will vary as firms age. As firms grow, their dependency may shift towards networks of more strategic and calculative nature (e.g., suppliers, customers, collaborators and partners become more important) and less reliant on the owners' social networks (Almeida et al., 2003). The shift is also accompanied by the evolution from more pre-existing interpersonal networks to more intentionally managed networks based on reputation and access to relevant resources and partners (Hite and Hesterly, 2001). A motivation for this change is highlighted by Westlund and Bolton (2003) who outline some of the negative aspects of social networks among entrepreneurial firms, arguing that the strong trust embedded in interpersonal relations can inhibit firm-level development.

A shift away from these interpersonal networks becomes evident when firms enage more in the formation of strategic alliances based on formalized collaboration and joint ventures, and other 'contracted' relationships involving equity and $\mathrm{R} \& \mathrm{D}$ agreements (Goerzen, 2005; Goerzen and Beamish, 2005; Grant, 1996; Grant and Baden-Fuller, 2004; 
Ireland et al., 2002; Stuart, 2000). However, as firms become more established, and potentially less vulnerable, the demand for network formation may initially fall, although over time increased reputation and status may increase the opportunity to form valuable network ties, resulting in an upward trend in the long-term (Eisenhardt and Schoonhoven, 1996; Lerner and Merges, 1998; Deeds and Hill, 1996; Stern et al., 2014). These potential changes in of the nature of and frequency of knowledge network activity are captured by the following hypotheses:

Hypothesis 1: The knowledge networks of firms evolve over their lifecycle, reflecting associated changes in needs, capabilities, and characteristics.

Hypothesis 2: The types of knowledge and the sources from which firms access knowledge change over their lifecycle, reflecting associated changes in needs, capabilities, and characteristics.

\subsection{The Spatial Dynamics of Networks}

Concomitant with the emergence of a deeper understanding of the temporal dynamics of networks, a significant change has occurred in the discourse on the spatial aspects of knowledge sourcing networks. Within debates concerning inter-organisational networks, the roles of space are recognised as increasingly important features of network structure and operation (Pittaway et al., 2004; Davenport, 2005; Iyer et al., 2005; Giuliani, 2007; Glückler, 2007; Knoben, 2009; Mancinelli and Mazzanti, 2009; Huber, 2011; Shearmur, 2011; Ter Wal and Boschma, 2011; Doran et al., 2012; Molina-Morales and Expósito-Langa, 2012). A key feature of this discourse has long concerned the role of networks of spatially proximate and co-located external organisations, such as universities, R\&D labs, and other firms or individuals, within the innovation process (Keeble et al., 1999; Brown and Duguid, 2001; Cooke et al., 2004; Huggins and Izushi, 2007; Laursen et al., 2012; Mattes, 2012). Implicit in the argument stemming from observations of advanced local and regional economies is that the skills gained through local interactions in such knowledge-rich environments better prepares firms for obtaining knowledge from distant sources, allowing them to benefit more from overseas knowledge (Sturgeon, 2003; Saxenian, 2005; Ter Wal and Boschma, 2011).

Underlying this emphasis on local interactions are uncertainties in the process of network development. External knowledge sourcing activities are often subject to considerable uncertainty, which often forces firms to go through a period of trial and error to 
build up an understanding of the norms, habits, and routines concerning different external knowledge channels (Cohen and Levinthal, 1990; Laursen and Salter, 2006). The success of external knowledge sourcing hinges to a large extent on a cumulative process of learning-bydoing. In view of the greater uncertainties involved in obtaining knowledge from distant locations, firms are most likely to draw on those experiences they have gained from local interactions if they can (Huggins and Izushi, 2007).

With the recognised role of spatial proximity to network development, there is an increasing emphasis on the importance of understanding networks and knowledge flows in an environment that is simultaneously local and global (Bathelt et al., 2004; Simard and West, 2006; Andersson and. Karlsson, 2007; Lorentzen, 2008; Van Geenhuizen, 2008; Maggioni and Uberti, 2009; Laursen et al., 2011; Broekel and Boschma, 2012; Doran et al., 2012). In general, the constraining effect of distance on knowledge flow and transfer is considered by some to be gradually diminishing, and there is increasing evidence of the heightened role being played by international knowledge sourcing networks in many places across the globe (Athreye, 2004; Doloreux, 2004; Garnsey and Heffernan, 2005; Saxenian, 2005). Many firms do not acquire their knowledge from within geographically proximate areas, particularly those firms based upon innovation-driven growth where knowledge is often sourced internationally (Davenport, 2005). If applicable knowledge is available locally, firms and other organisations will attempt to source it; if not they will look elsewhere (Drejer and Lund Vinding, 2007).

The key aspect of these developments is that the knowledge base of the world's most advanced local and regional economies is no longer necessarily local, but also positioned within global knowledge networks (Wolfe and Gertler, 2004; Huggins and Izushi, 2007; Lorentzen, 2008). There is also a growing school of thought that non-proximate actors are often equally, if not better, able to transfer strategically relevant and valuable knowledge across such spatial boundaries providing a high performing network structure is in place (McEvily and Zaheer, 1999; Dunning, 2000; Lissoni, 2001; Davenport, 2005; Palazzo, 2005; Zaheer and Bell, 2005; Teixeira et al., 2006; Torre, 2008).

The differing spatial dynamics of knowledge sourcing activity suggests that there is potentially some interdependency between the local and global networks. In particular, successful connectivity in global spaces is often considered to be the outcome of an initial system of localised interaction, whereby it is the knowledge crossing hallways and streets that initially catalyses intellectual exchange and knowledge transfer across oceans and continents (Glaeser et al, 1992). This phased transition is necessitated by the risk of firms becoming 
rigid and outdated when local networks fail to keep abreast of knowledge emerging outside of their respective region (Camagni, 1991; Izushi, 1997; Bathelt et al., 2004; Ter Wal and Boschma, 2011). However, not all firms may participate in the transition from local to global interactions. Whereas firms with less resources and lower absorptive capacity (Cohen and Levinthal, 1990) may tend to continue to network mainly locally, those with greater resources and higher absorptive capacity are likely to be more connected to global networks (Drejer and Lund Vinding, 2007; Van Geenhuizen, 2008; Huggins and Johnston, 2009). Based on the above, the following is suggested:

Hypothesis 3: The geographical location of the knowledge sources utilised by firms change over their lifecycle, reflecting associated changes in needs, capabilities, and characteristics.

\section{Methodology}

The empirical part of this paper is based on data collected from a survey of 3,622 firms in the UK administered in 2009 on firm knowledge sourcing practices. The sample of firms was constructed from multiple regional and local directories of firms. Overall, the survey sought to capture firms with a potential propensity towards innovation, and therefore the key source in preparing the sample was a systematic mining of listings of firms based on science and technology parks, and business incubators in the UK. Data for the sample was enriched with firm-specific data derived from the FAME (Financial Analysis Made Easy) business database, which provided registered office address (important in the regional context), detailed sector classification (in the coding of UK Standard Industry Classification 2007), and employment data, as well as the year of incorporation, for which it is regarded a reliable and robust source of information (Ritchie and Evans, 2009). Not only ensuring the capability to define the structure of the sample, this also helped to triangulate reported data with secondary data.

The survey sample focused mainly on three broad sectors: manufacturing; information and communication; and professional, scientific, and technical activities. Accounting for $86.7 \%$ of the sample, they were expected to capture the majority of the firms involved in the knowledge-sourcing activities. The remainder of the sectors included agriculture; mining; construction; wholesale and retail trade, and repair of motor vehicles and motorcycles; financial, insurance and real estate activities; human health and social work activities; arts, entertainment and recreation; and other service activities. As for firm size, the sample was formulated around firms of all sizes, with the composition consisting of $79.6 \%$ small firms 
(50 or less employees - 61\% of which had 10 or less employees), 12.8\% medium firms (51250 employees), and 7.7\% large firms (251 plus employees). In terms of geographical distribution, $42.7 \%$ of firms in our sample were located in South East, East of England, and London regions of the UK. The lowest proportion of firms came from Northern Ireland, Wales and North East regions (2.0\%, 3.1\%, and 3.3\% respectively), which is representative of the distribution of the population of all active firms (Office for National Statistics, 2010).

The questionnaire was administered by post and achieved a response rate of $10.9 \%$, which constituted 393 responses. For our current analytical purposes, we then selected 299 firms that answered all questions relevant to this paper's analysis. In comparison with the sampled firms, $\chi^{2}$-test found that the selection was similar in terms of sectors, sizes, geographical location, and firm age, as shown by Table 1. In terms of age, firms are classified into the following three groups: 0-5 years; 6-10 years; and 11 or more years old, which relates to similar classifications identified in the literature (Eisenhardt and Schoonhoven, 1996; Moreno and Casillas, 2008). The overall breakdown of the respondents by age is: 64 firms (21.4\%) for 0-5 years of age; 98 firms (32.8\%) for 6-10 years of age; and 137 firms (45.8\%) for 11 or more years of age, with again the responses being representative of the survey sample.

\section{Table 1 About Here}

The survey collected information on knowledge sourcing activities by the type and location of knowledge sources, as well as firm profiles, with a mix of ordinal and scale data through the use of Likert scales and open numerical questions. To measure levels of knowledge sourcing activities at different geographical levels, each firm was asked to rate, on an 11point Likert scale ( 0 = never, $10=$ very often), their frequency of use for each of the following eight knowledge sources: (1) suppliers of equipment, materials, services, and software; (2) clients and customers; (3) competitors and other businesses in the firm's industry; (4) consultants; (5) commercial labs and private R\&D institutes; (6) universities and other higher education institutes; (7) government and public research institutes; and (8) conferences, trade fairs, and exhibitions. The question was repeated for each of three geographical levels: (1) within the firm's own region; (2) within the rest of the UK; and (3) outside the UK. In a similar vein, on an 11-point Likert scale, firms were also asked to identify the frequency of accessing external sources by the forms of knowledge accessed, covering: professional information and intelligence, skills and expertise, market or competitor 
intelligence, new technology, scientific information, and R\&D. Finally, firms were asked to identify the number of product, process, and organisational innovations they made during the last three years (or since their foundation for start-ups of less than three years old).

The three geographical levels utilised by the study are a means of ascertaining whether the shift from more regional to more global networks, discussed earlier, is evident as firms' age. For an 'island nation' such as the UK the choice between sourcing knowledge from national or international knowledge sources is likely to be purposeful for most firms. ${ }^{1}$ NUTS1 level regions are used to provide the distinction between local and non-local knowledge, which follows work that considers regions to be the primary spatial units that: compete to attract investment; circulate and transfer knowledge, resulting in agglomerations, or clusters, of industrial and service sector enterprises, i.e. regions being relatively distinct economic and organizational spatial entities (Scott, 1995; Cooke, 1997; Amin, 1999; Werker and Athreye, 2004; Malecki, 2007). Nevertheless, it is noted that regional boundaries are to an extent administratively determined and may not reflect the full extent of what may be considered localised social and economic interactions and transactions.

In cases where data from single informant is relied upon there is a danger that the design or administration of the questionnaire can introduce common method variance (CMV) (Podsakoff et al., 2012; Gorrell et al., 2011). In order to reduce the likelihood of CMV the length of the questionnaire was minimised to reduce the cognitive effort, which can lead to CMV (Krosnick, 1999). As a means of examining whether CMV remained a problem, confirmatory factor analysis was employed to conduct a single-factor test on all measured variables. If $\mathrm{CMV}$ is present a single factor model should fit the data as well as a more complex model. In this case, the goodness of fit statistics for a single factor model (CFI=0.32 and RMSEA=0.16) showed a poor fit, suggesting that CMV is not an issue. However, the single factor test has been criticised as being insensitive to small or moderate levels of CMV when the model includes many variables (Podsakoff and Organ, 1986; Podsakoff et al., 2003) or a single factor accounts for a majority of the variance (Lindell and Whitney, 2001; Gorrell et al., 2011). As a check to determine whether or not this is a potentially residual problem, we examine the Cronbach's alpha statistic as a further means of idenfying an indication of CMV bias (Gorrell et al., 2011). In this case, there is no evidence of CMV, with the alphas of the eight sources at the three geographical levels falling in the range 0.74 to 0.82 , reflecting

\footnotetext{
${ }^{1}$ The exception to this may be for those firms based in Northern Ireland where a land border with the Republic of Ireland may reduce practical and psychological barriers to international networking. In the analysis regional idiosyncrasies such as this are controlled for through the inclusion of regional dummies.
} 
consistencies that are not exceedingly high. A final check employed the theoretically unconnected 'marker variable' approach (Lindell and Whitney, 2001; Gorrell et al., 2011). The frequency of accessing firm-based knowledge sources such as suppliers, customers, and other businesses and its relationship with accessing non-firm based sources such as universities, public research institutes, and commercial labswere analyzed as means of identifying an interrelationships. An examination of all pairs of subjective items reveals correlations as low as 0.01 (and the second-lowest being 0.02) between the use of the two groups of sources (Jimmieson et al., 2008; Zhang and Chen, 2008). Therefore, CMV does not appear to be an issue in the survey data.

The analysis consists of three key modes: first, an analysis of the key descriptive statistics generated from the survey data; second, a factor analysis of the variables relating to the key knowledge sources, and their location, utilised by firms, and third, an analysis of an ordinary least squares (OLS) regression model. Factor analysis is applied to the utilisation frequencies at each geographical level in order to merge the responses into a fewer number of mutually orthogonal indicators, which preserves as much as possible of the initial information. $^{2}$ Due to relatively strong cross-loadings across factors, sourcing from consultants was dropped from the analysis. Analysing a scree plot and non-trivial variance (Cattell, 1966; Gorsuch, 1983), two factors were identified at each of the geographical levels. A goodness of fit test of the factor model obtains the chi-square value of 491.33, 352.99, and 714.31 for the three geographical levels, namely, regional, the rest of UK, and overseas respectively, and the significance value of 0.00 for all the three geographical levels, showing highly satisfactory results.

Table 2 shows the rotated factor matrix obtained by the varimax method, indicating how the original eight variables except for consultants are loaded onto the two factors identified at each of the geographical levels. At each of the three geographical levels (1) suppliers of equipment, materials, services, and software, (2) clients and customers, (3) competitors and other businesses in the firm's industry, and (8) conferences, trade fairs, and exhibitions are heavily loaded onto the first factor, which is labeled here as 'firm based knowledge sources'. By contrast, (5) commercial labs and private R\&D institutes, (6) universities and other higher education institutes, and (7) government and public research institutes are dominant in the second factor labeled as 'non-firm based knowledge sources'.

\footnotetext{
${ }^{2}$ For the extraction of factors, the principal factor method was used. Initially we attempted the maximum likelihood method but could not find an interior solution to the factor maximum likelihood (i.e. boundary solutions produce uniqueness of 0 , which cannot be theoretically justified).
} 
The loadings for the two factors are broadly consistent with the findings of other studies (e.g., Roper et al., 2008; Doran and O’Leary, 2011). Based on the rotated factor matrix obtained, two factor scores are computed at each of the geographical levels. For this computation, the regression scoring method was employed, which is known for producing more accurate scores than the Bartlett scoring method (Thomson, 1951). The obtained scores for the firm based and non-firm based knowledge sources at the three geographical levels represent the extent to which knowledge is drawn from the sources.

Table 2 About Here

In the regression analysis, we control for firm size (based on a natural log of employees to reduce the influence of outliers and skewed distributions), sector, firm location, affiliation as a subsidiary, and the level of an absorptive capacity. On firm size, previous empirical studies of firm innovation and its temporal changes typically separate the effects of firm size from other factors (e.g. Hansen, 1992; Sørensen and Stuart, 2000; Huergo and Jaumandreu, 2004; Balasubramanian and Lee, 2008; Withers et al., 2011). To account for other sources of firm heterogeneity in our sample, 18 sectoral groups are also controlled for at the two-digit level of UK Standard Industrial Classification (SIC) 2007. Furthermore, the location of firms has bearing upon the use of knowledge networks. Numerous studies find that the geographical proximity of external knowledge sources has an impact upon the firm's decision to use them (e.g., Keeble et al, 1991; Mackun and MacPherson, 1997; Bennett et al., 2000), and the availability of knowledge sources vary by location. In view of this, dummies are included to distinguish firm location by 12 NUTS1 government regions in the UK. Firms are also distinguished according to whether they are a subsidiary or not, as subsidiaries can draw on their parent organisations' resources when searching and absorbing knowledge. Finally each firm in the survey was asked to rate its absorptive capacity with a 4-point Likert scale (from 'not sufficient' to 'extremely sufficient'). Table 3 shows the descriptive statistics for the variables included in the regression analysis.

Table 3 About Here

\section{Results}

Initially, it is useful to illustrate how the rates of turnover growth and innovation change based on the age of responding firms. Figure 1 shows the relationship between the rate of 
turnover growth and firm age. It can be seen that turnover growth tends to peak in the period between 5 and 10 years, inevitably rising from a low baseline. Following this period, turnover growth tends to follow a more stable pattern in period of 10 to 25 years of age and beyond. Overall, it is clear that the rate of turnover growth shows a curvilinear relationship with firm age, which is manifested in the form of inverted U-shape, with an apex emerging following the early start-up years, but appearing before a more mature phase is entered.

Figure 1 About Here

Figure 2 shows the average number of innovations introduced by type and by groups of firm age. Firms are categorized into the following three groups: relatively new start-ups ( $0-5$ years of age); medium-aged firms that started 6 to 10 years ago, which corresponds to the peak in the rate of turnover growth identified above; and the more mature firms that started 11 or more years ago. In general, there is a linear relationship between these factors, with a greater number of innovations observed among firms in the older age groups. The slope is the steepest for product innovations, whilst the increases in process and organisational innovation are more modest. A sector analysis finds that manufacturing firms are more innovative than service sector firms across all three types of innovation measured.

\section{Figure 2 About Here}

Table 4 indicates descriptive statistics for the frequency of accessing a range of network sources. This is the case for the sample as a whole and within the subgroups of firms split by age. Overall, it can be seen that across all firms the supply-chain, in the form of knowledge sourced from customers and suppliers, is the most frequently used source, followed by the use of conferences/trade fairs and competitors. The least used sources are commercial laboratories and government research institutes. This general trend mirrors a range of existing evidence on relative differences in the use of various types of network knowledge sources (Freel, 2000; 2003; Huggins et al., 2012). In this case, however, different trends depending on the age of the firm can be identified. In particular, the frequency of sourcing knowledge is generally lowest for those firms started between 6 to 10 years ago (with the only exception being the use of customers and universities). 
Figure 3 presents a breakdown of external knowledge sourcing by location of source (Doran et al., 2012; Mattes, 2012). It shows the frequency of accessing knowledge from (1) sources based in the same region as the firm, (2) sources in the UK other than those in the same region as the firm, and (3) sources overseas, as well as the average of the three. Overall, sources based in other regions of the UK tend to be the most frequently accessed for all types of sources. This suggests that the geographic nature of the knowledge networks of these firms is at least as national as it is regionally-bounded. This is somewhat contrary to certain theories such as those related to regional innovation systems and clusters, which suggest the pre-eminence of local and regional networks (Camagni, 1991; Cooke et al., 2004; Capello and Faggian, 2005). By contrast, knowledge from overseas sources tends to be less frequently utilised compared with the use of domestic sources, regardless of whether these domestic network sources are based in the same region or based in the wider national arena. A Ushaped relationship is again observed for the three firm age groups across the three geographical levels, with the frequency of knowledge sourcing showing a dip in the 6 to 10 year growth period, compared with $0-5$ and 11 plus periods.

\section{Figure 3 About Here}

The pattern is repeated when the form of knowledge being sourced is examined. Using the STI-DUI typology of innovation modes (Jensen et al., 2007), it can be suggested that while new technology, scientific information, and R\&D relate to STI knowledge modes of innovation, skills and expertise, professional information, and market intelligence relate more to DUI knowledge modes of innovation, which are accessed through on-going networks within the supply-chain as well as horizontally through collaboration and cooperation with competitors and partners. Figure 4 shows a graphic presentation of the frequency of sourcing DUI-type knowledge by firm age, taking an average of responses to 11-point Likert scale question ( 0 = never, 10 = very often). In this case, a U-shaped relationship is again found, with the group of firms of 6 to 10 years old being far less likely to engage in accessing this form of knowledge. During this phase when the highest rate of turnover growth is observed (Figure 1), firms appear to retreat, in relative terms, from the collaboration and cooperation associated with doing-using-interacting forms of knowledge exchange. 
Although the descriptive statistics suggest the possibility that the evolution of firms has a curvilinear relationship with the dynamism of the knowledge networks, it is clearly important to control for other factors, and in particular to separate firm size from other factors. To achieve this, Table 5 shows results of the regression analysis for knowledge sourcing from 'firm based knowledge sources' at the three geographical levels. As the null hypothesis of homoscedasticity was not rejected by Breusch-Pagan/Cook-Weisberg tests, OLS is employed for model estimation. Natural log of employees takes a positive sign at all the three geographical levels. Taking a greater coefficient with a wider geographical scale, the variable enters the model highly significantly for knowledge sourcing elsewhere in the UK and overseas. This means that larger firms access firm based knowledge sources such as suppliers, customers, and competitors located outside their own region more frequently when compared with smaller firms.

When firm size is held constant, there are relatively small differences between startups of 0 to 5 years old and older firms with regard to accessing the sources within their own region. By contrast, older firms source knowledge from firm based sources outside their own region less frequently than firms at their initial start-up phase. This difference is more pronounced for sources outside the nation, with those firms started more than 10 years ago showing a significant drop at the $5 \%$ level. Given an increased level of cross-border supply chain management in recent years, there is a possibility that the differences observed between start-ups started in the last 5 years and older firms are due to changes in those external environments at the time of birth which may cement knowledge sourcing behaviours. Otherwise, the lower frequency of access shown by older firms is likely to suggest that, when firm size is held constant, the usage of firm based knowledge sources outside a firm's own region declines as the firm ages, particularly when it enters the mature period of over 10 years since its foundation. In other words, those firms which remain unchanged in their size become less reliant upon firm based knowledge sources outside their own region in the growth and mature periods, whilst the particular sources within their own region gain in relative importance. This largely conforms to the the pre-eminence of local and regional networks envisaged by theories of regional innovation systems and clusters.

As for other control variables, subsidiary firms are more active in accessing firm based knowledge sources outside the country than non-subsidiary firms at the $1 \%$ significance level, suggesting that the resources of their parent organisations help subsidiaries to access the overseas sources. Finally, the level of absorptive capacity enters the model for 
accessing the particular sources located elsewhere in the UK and overseas at the $10 \%$ and $1 \%$ level respectively. The negative coefficient sign suggests that the perceived level of absorptive capacity reflects a firm's capacity for knowledge filtering, with firms possessing a higher level of this capacity being more selective in the choice and use of firm based knowledge sources outside their own region, resulting in less frequent use.

\section{Table 5 About Here}

Table 6 presents results of the regression analysis for accessing 'non-firm based knowledge sources' at the three geographical levels. With the null hypothesis of homoscedasticity rejected in Breusch-Pagan/Cook-Weisberg tests, heteroskedasticity-robust OLS was employed for model estimation. Firms at the 6 to 10 years of age access non-firm based knowledge sources within their own region less frequently at the $5 \%$ level, compared with those at the initial start-up period of 0 to 5 years. While somewhat recovering, the usage frequency of the regional sources remains lower for firms at the mature period of over 10 years of age than firms at the initial start-up period. In contrast, there are no significant relationships between firm age and knowledge sourcing outside a firm's own region although the coefficients for both firm age dummies (6-10 years, and 11 years and over) take a positive sign for overseas access. Unless deriving from historical conditions at birth, this suggests that the relative importance of non-firm based knowledge sources within a firm's own region drops after the initial start-up period.

The natural log of employees takes a positive sign at all the three geographical levels, particularly entering the model at the $10 \%$ level for overseas access. However, when compared with the use of firm based knowledge sources, the coefficients are relatively small, suggesting that an increase in the use of non-firm based knowledge sources due to increased firm resources is less marked. Also, the dummy for subsidiary takes a positive sign at all the three geographical levels with the overseas sources entering the model at the $10 \%$ level, meaning that the advantage given by the resources of parent organisations is evident for overseas knowledge sourcing from firm and non-firm based sources.

Table 6 About Here

\section{Discussion and Conclusion}


Overall, the results indicate that the U-shaped relationship observed across the three age groups of firms is an interwoven outcome of firm size and age. Furthermore, the results offer broad support for the hypotheses generated earlier, with the knowledge networks of firms appearing to evolve as the needs, capabilities, and characteristics of firms change in line with their position at particular points in their lifecycle. In particular, at the emergence phase, knowledge sourcing is at its peak. This indicates that during this emergence phase, entrepreneurial firms make significant investments in networks as a means of accessing the knowledge they require (Baum et al., 2000; Athreye, 2004; Garnsey and Heffernan, 2005). This is consistent with research suggesting that the demand for network formation is greatest for firms in more vulnerable situations (Eisenhardt and Schoonhoven, 1996). Furthermore, entrepreneurial firms tend to invest in the types of knowledge associated with the DUI mode of innovation (Jensen at al., 2007), which resonates with the view that at the entrepreneurial stage firms engage in learning through relatively close and collaborative interactions with their knowledge sources, especially customers, suppliers, and universities. However, as others have noted (Lechner and Dowling, 2003), there is not necessarily parity of esteem between entrepreneurial firms and those organisations from which they source knowledge.

The location of knowledge sources, as well as the forms of knowledge and types of knowledge sources, show a variation across age groups, with the results most significantly pronounced for firm based knowledge sources such as suppliers, customers, and other businesses. In particular, firms tend to less frequently access knowledge from other firms outside their own region (particularly outside the country) as they enter a mature phase. Firms may have formed long-lasting relationships with a core group of collaborators (Belussi and Sedita, 2012; Lawton Smith et al. 2012), and in some cases they may have even attracted important knowledge sources to their regions through their supply-chains (Martin and Sunley, 2007; Ter Wal and Boschma, 2011). As for non-firm based sources, firms tend to access less frequently sources in their own region as they enter a stage of peak growth. Furthermore, for both the firm based and non-firm based knowledge sources, larger-scale firms tend to more frequently access sources outside their own region.

The potential paradox contained within the results is the drop in knowledge sourcing activity between the emergence and growth phases, which is significantly marked in the case of accessing knowledge from non-firm based sources within the firms' own region. In many ways, however, it fits the view that the relationship between investments in network capital on the one hand and turnover growth and innovation on the other are likely to be lagged (Pittaway et al., 2004; Tomlinson, 2010). During the emergence phase, a key priority for 
entrepreneurial firms seeking to innovate is to build their absorptive capacity, which is necessarily likely to be relatively low during this phase (Hite and Hesterly, 2001; Wiklund and Shepherd, 2003). Also, network investments are likely to form a high proportion of overall investments as they search, screen, and select knowledge sources and potential network partners (Drejer and Lund Vinding, 2007). In other words, the emergence phase is a period of both high rates of network generation and subsequent new knowledge accumulation (March, 1991; Nonaka and Takeuchi, 1995; Quatraro, 2010; Huggins, 2010; Huggins and Thompson, 2014).

In terms of public policy, the results indicate that policymakers need to be aware that firms make use of different forms of networks during different stages of the lifecycle, with the types of sources, forms of knowledge, and location of sources varying over time. In the past, most network initiatives aimed at entrepreneurial firms have supported firms in developing networks with local actors, particularly through the use of local cluster initiatives and the like (Porter, 1998; Huggins and Izushi, 2011). However, it is clear that whilst entrepreneurial firms do engage in local knowledge networks, they are also significantly involved in wider national and international networks. In a network sense, cluster-related policy has concerned the promotion of network initiatives seeking to promote long-term local stable relationships, but often lacking clear objectives - and the formulation of spatially bounded inter-organisational networks. The findings suggest that investments in network capital and the formulation of relatively dynamic network configurations are also of key importance.

Finally, it should be noted that this paper is clearly not without its limitations. As indicated, the analysis presented here is necessarily exploratory and the cross-sectional nature of analysis does not allow for controlling for a range of environmental factors, which may impact on the evolution of firm networks. If a firm's knowledge sourcing behaviour is strongly influenced and cemented by the external environment at its birth, there is a possibility that the three groups of firms in our sample may have been subject to different environmental conditions, which may have lingering effects upon knowledge sourcing at later stages in their evolution. Most notably, Internet-based devices and networks have gone through rapid changes even in the span of the last ten to fifteen years, providing increased opportunities of communication and trade across national borders. Such changes in external environments may have different impacts upon the firms in our sample, potentially biasing the estimates presented above. Given the potential for endogeneity due to historical conditions, our estimates of firm age effects, therefore, should be viewed as explorative rather 
than conclusive. Nevertheless, they do suggest that networks are likely to possess a number of evolutionary characteristics.

\section{References}

Abernathy, W. J. and Utterback, J. M. (1978) 'Patterns of industrial innovation', Technology Review, 80, 41-47.

Adler, P. S. and Kwon, S. W. (2002) 'Social capital: prospects for a new concept', Academy of Management Review, 27 (1), 17-40.

Agarwal. R. and Gort, M. (2002) 'Firm and product life cycles and firm survival', American Economic Review, 92(2), 184-190.

Ahuja, G. (2000) 'The duality of collaboration: inducements and opportunities in the formation of interfirm linkages', Strategic Management Journal, 21 (3), 317-343.

Almeida, P., Dokko, G. and Rosenkopf, L. (2003) 'Startup size and the mechanisms of external learning: increasing opportunity and decreasing ability?', Research Policy, 32 (2), 301-315.

Amin, A. (1999) 'An institutionalist perspective on regional economic development', International Journal of Urban and Regional Research, 23 (2), 365-378.

Anderson, A., Park, J., and Jack, S. (2007) 'Entrepreneurial social capital: conceptualizing social capital in new high-tech firms', International Small Business Journal, 25 (3), 245-272.

Anderson, A., Dodd, S. D., and Jack, S. (2010) 'Network practices and entrepreneurial growth', Scandinavian Journal of Management, 26 (2), 121-133.

Andersson, M. and Karlsson, C. (2007) 'Knowledge in regional economic growth: the role of knowledge accessibility', Industry and Innovation, 14 (2), 129-149.

Arthur, B. (1989) 'Competing technologies and lock-in by historical events: the dynamics of allocation under increasing returns', Economic Journal, 99 (394), 116-131.

Athreye, S. (2004) 'Agglomeration and growth: a study of the Cambridge hi-tech cluster', In Bresnahan, T. and Gambardella, A. (eds), Building high-tech clusters Silicon Valley and beyond, Cambridge \& New York: Cambridge University Press.

Balasubramanian, N. and Lee, J. (2008) 'Firm age and innovation', Industrial \& Corporate Change, 17 (5), 1019-1047.

Balland, P.-A., De Vaan, M., and Boschma, R. (2013) 'The dynamics of interfirm networks along the industry life cycle: the case of the global video game industry, 1987-2007', Journal of Economic Geography, 13 (5), 741-765.

Bathelt, H. and Turi, P. (2011) 'Local, global and virtual buzz: the importance of face-to-face contact in economic interaction and possibilities to go beyond', Geoforum, 42 (5), 520-529.

Bathelt, H., Malmberg, A., and Maskell, P. (2004) 'Clusters and knowledge: local buzz, global pipelines and the process of knowledge creation', Progress in Human Geography, 28 (1), 31-56.

Barney, J. (1991) 'Firm resources and sustained competitive advantage', Journal of Management, 17 (1), 99-120.

Baum, J., Calabrese, T., and Silverman, B. S. (2000) 'Don't go it alone: alliance network composition and startups' performance in Canadian biotechnology', Strategic Management Journal, 21 (3), 267-294.

Belussi, F. and Sedita, R. (2012) 'Industrial districts as open learning systems: combining emergent and deliberate knowledge structures’, Regional Studies, 46 (2), 165-184. 
Bennett, R. J., Bratton, W. A., and Robson, P. J. (2000) 'Business advice: the influence of distance', Regional Studies, 34 (9), 813-828.

Bergenholtz, C. and Waldstrøm, C. (2011) 'Inter-organizational network studies: a literature review’, Industry and Innovation, 18 (6), 539-562.

Boschma, R. and Frenken, K. (2006) 'Why is economic geography not an evolutionary science? Towards an evolutionary economic geography', Journal of Economic Geography, 6 (3), 273-302.

Broekel, T. and Boschma, R. (2012) 'Knowledge networks in the Dutch aviation industry: the proximity paradox', Journal of Economic Geography, 12 (2), 409-433.

Brown, J. S. and Duguid, P. (2001) 'Knowledge and organization: a social practice perspective’, Organizational Science, 12 (2), 198-213.

Camagni, R. P. (1991) 'Local 'milieu', uncertainty and innovation networks: towards a new dynamic theory of space’, In Camagni, R. P. (ed.), Innovation networks, London: Belhaven Press, pp. 121-144.

Capello, R. and Faggian, A. (2005) 'Collective learning and relational capital in local innovation processes', Regional Studies, 39 (1), 75-87.

Cattell, R. B. (1966) 'The scree test for the number of factors', Multivariate Behavioral Research, 1, 245-276.

Cohen, W. M. and Levinthal, D. A. (1990) 'Absorptive capacity: a new perspective on learning and innovation', Administrative Science Quarterly, 35 (1), 128-152.

Contractor, F. and Lorange, P. (2002) 'The growth of alliances in the knowledge-based economy', International Business Review, 11 (4), 485-205.

Cooke, P. (1997) 'Regions in a global market: the experiences of Wales and Baden Württemberg', Review of International Political Economy, 4 (2), 349-381.

Cooke, P., Heidenreich, M., and Braczyk, H. (eds.) (2004) Regional Innovation Systems: The role of Governance in a Globalised World, London: Routledge.

D’Agostino, R. B., Belanger, A., and D’Agostine, Jr., R. B. (1990) 'A suggestion for using powerful and informative tests of normality', American Statistician, 44 (4), 316-321.

Davenport, S. (2005) 'Exploring the role of proximity in SME knowledge-acquisition', Research Policy, 34 (5), 683-701.

Deeds, D. L. and Hill, C. W. L. (1996) 'Strategic alliances and the rate of new product development: an empirical study of entrepreneurial biotechnology firms', Journal of Business Venturing, 11 (1), 41-51.

Doloreux, D. (2004) 'Regional innovation systems in Canada: a comparative study', Regional Studies, 38 (5), 479-492.

Doran, J. and O'Leary, E. (2011) 'External interaction, innovation and productivity: an application of the innovation value chain to Ireland;, Spatial Economic Analysis 6 (2), 199-222.

Doran, J., Jordan, D., O’Leary, E. (2012) 'The effects of the frequency of spatially proximate and distant interaction on innovation by Irish SMEs', Entrepreneurship \& Regional Development, 24 (7-8), 705-727

Drejer, I. and Lund Vinding, A. (2007) 'Searching near and far: determinants of innovative firms' propensity to collaborate across geographical distance', Industry and Innovation, 14 (3), 259-275.

Dunning, J. H. (2000) 'Regions, globalization, and the knowledge economy: the issues stated', in Dunning, J. H. (ed.) Regions, globalization, and the knowledge-based economy, Oxford: Oxford University Press, pp. 7-41.

Eisenhardt, K. M. and Schoonhoven, C. B. (1996) 'Resource-based view of strategic alliance formation: strategic and social effects in entrepreneurial firms’, Organization Science, 7 (2), 136-150. 
Freel, M. (2000) 'External linkages and product innovation in small manufacturing firms', Entrepreneurship \& Regional Development, 12 (3), 245-266.

Freel, M. S. (2003) 'Sectoral patterns of small firm innovation, networking and proximity', Research Policy, 32 (5), 751-770.

Gargiulo, M. and Benassi, M. (2000) 'Trapped in your own net? Network cohesion structural holes, and the adaptation of social capital', Organization Science, 11 (2), 183-196.

Garnsey, E. and Heffernan, P. (2005) 'High-technology clustering through spin-out and attraction: the Cambridge case', Regional Studies, 39 (8), 1127-1144.

Giuliani, E. (2007) 'The selective nature of knowledge networks in clusters: evidence from the wine industry', Journal of Economic Geography, 7 (2), 139-168.

Glaeser, E. L., Kallal, H. D., Scheinkman, J. A., and Shleifer, A. (1992) 'Growth in cities', Journal of Political Economy, 100 (6), 1126-1152.

Glückler, J. (2007) 'Economic geography and the evolution of networks', Journal of Economic Geography, 7 (5), 619-34.

Goerzen, A. (2005) 'Managing alliance networks: emerging practices of multinational corporations', Academy of Management Executive, 19 (2), 94-107.

Goerzen, A. and Beamish, P. W. (2005) 'The effect of alliance network diversity on multinational enterprise performance', Strategic Management Journal, 26 (4), 333354.

Gorrell, G., Ford, N., Madden, A., Holdridge, P., and Eaglestone, B. (2011) 'Countering method bias in questionnaire-based user studies', Journal of Documentation, 67 (3), 507-524.

Gorsuch, R. L. (1983) Factor Analysis, 2nd ed. Hills Dale, NJ: Lawrence Erlbaum Associates.

Grant R. (1996) 'Toward a knowledge-based theory of the firm', Strategic Management Journal, 17 (Winter Special Issue), 109-122.

Grant, R. and Baden-Fuller. C. (2004) 'A knowledge accessing theory of strategic alliances', Journal of Management Studies, 41 (1), 61-84.

Greve, A. and Salaff, J. W. (2003) 'Social networks and entrepreneurship', Entrepreneurship Theory and Practice, 28 (1), 1-22.

Gulati, R. (1999) 'Network location and learning: the influence of network resources and firm capabilities on alliance formation’, Strategic Management Journal, 20 (5), 397420.

Hansen, J. A. (1992) 'Innovation, firm size, and firm age', Small Business Economics, 4 (1), 37-44.

Hatzichronoglou, T. (1997) 'Revision of the high-technology sector and product classification', STI Working Papers, 2. OECD, Paris.

Hite, J. and Hesterly, W. S. (2001) 'The evolution of firm networks: from emergence to early growth of the firm', Strategic Management Journal, 22 (3), 275-86.

Howells, J. (1996) 'Tacit knowledge, innovation and technology transfer', Technology Analysis \& Strategic Management, 8 (2), 91-106.

Huergo, E. and Jaumandreu, J. (2004) 'How does probability of innovation change with firm age?', Small Business Economics, 22 (3-4), 193-207.

Huggins, R. (2010) 'Forms of network resource: knowledge access and the role of interfirm networks’, International Journal of Management Reviews, 12 (3), 335-352.

Huggins, R. (2011) 'The growth of knowledge-intensive business services: Innovation, markets and networks', European Planning Studies, 19 (8), 1459-1480.

Huggins, R. and Izushi, H. (2007) Competing for Knowledge: Creating, Connecting and Growing, London: Routledge.

Huggins, R. and Izushi, H. (eds) (2011) Competition, Competitive Advantage, and Clusters: The Ideas of Michael Porter. Oxford: Oxford University Press. 
Huggins, R. Johnston, A. (2009) 'Knowledge networks in an uncompetitive region: SME innovation and growth', Growth and Change, 40 (2), 227-259.

Huggins, R. and Johnston, A. (2010) 'Knowledge flow and inter-firm networks: the influence of network resources, spatial proximity, and firm size', Entrepreneurship and Regional Development, 22 (5), 457-484.

Huggins, R. and Thompson, P. (2014) 'A Network-based view of regional growth', Journal of Economic Geography, 14 (3), 511-545

Huggins, R., Johnston, A., and Thompson, P. (2012) 'Network capital, social capital and knowledge flow: how the nature of inter-organizational networks impacts on innovation', Industry and Innovation, 19 (3), 203-232

Ireland, R. D., Hitt, M. A., and Vaidyanath. D. (2002) 'Alliance management as a source of competitive advantage', Journal of Management, 28 (3), 413-46.

Iyer, S., Kitson, M., and Toh, B. (2005) 'Social capital, economic growth and regional development', Regional Studies, 39 (8), 1015-1040.

Izushi, H. (1997) 'Conflict between two industrial networks: technological adaptation and interfirm relationships in the ceramics industry in Seto, Japan', Regional Studies, 31 (2), 117-129.

Jack, S. L. (2005) 'The role, use and activation of strong and weak network ties: a qualitative analysis', Journal of Management Studies, 42 (6), 1233-1259.

Jack, S., Dodd, S. D., and Anderson. A. (2008) 'Change and the development of entrepreneurial networks over time: a processual perspective’, Entrepreneurship and Regional Development, 20 (2), 125-159.

Jack., S., Moult, S., Anderson, A. R., and Dodd, S. (2010) 'An entrepreneurial network evolving: patterns of change’, International Small Business Journal, 28 (4), 315-337.

Jensen, M. B., Johnson, B., Lorenz, E., and Lundvall, B. A. (2007) 'Forms of knowledge and modes of innovation', Research Policy, 36 (5), 680-693.

Jimmieson, N. L., Peach, M., and White, K. M. (2008) 'Utilizing the theory of planned behavior to inform change management: an investigation of employee intentions to support organizational change', Journal of Applied Behavioural Science, 44 (2), 237262.

Johannisson, B., Ramírez-Pasillas, M., and Karlsson, G. (2002) 'The institutional emeddedness of local inter-firm networks: a leverage for business creation', Entrepreneurship and Regional Development, 14 (4), 297-315.

Keeble, D., Bryson, J., and Wood, P. (1991) 'Small firms, business services growth and regional development in the United Kingdom: some empirical findings', Regional Studies, 25 (5), 439-457.

Keeble, D., Lawson, C., Moore, B., and Wilkinson, F. (1999) 'Collective learning processes, networking and 'institutional thickness' in the Cambridge region', Regional Studies, 33 (4), 319-332.

Klepper, S. (1997) 'Industry life cycle', Industrial and Corporate Change, 6 (1), 145-181.

Knoben, J. (2009) 'Localized inter-organizational linkages, agglomeration effects, and the innovative performance of firms', Annals of Regional Science, 43 (3), 757-779.

Knoben, J. and Oerlemans, L. A. G. (2006) 'Proximity and inter-organizational collaboration', International Journal of Management Reviews, 8 (2), 71-89.

Kramera, J-P. and Revilla Diez, J. (2012) 'Catching the local buzz by embedding? Empirical insights on the regional embeddedness of multinational enterprises in Germany and the UK', Regional Studies, 46 (10), 1303-1317.

Kramera, J-P., Marinelli, E., Iammarino, S., and Revilla Diez, J. (2011) 'Intangible assets as drivers of innovation: empirical evidence on multinational enterprises in German and UK regional systems of innovation', Technovation, 31 (9): 447-458. 
Krosnick, J. A. (1999) 'Survey research’, Annual Review of Psychology, 50, 537-567.

Laafia, I. (1999) 'Regional employment in high technology', Statistics in Focus, Research and Development Theme, 9 (1), Eurostat, Luxembourg.

Labianca, G. and Brass, D. J. (2006) 'Exploring the social ledger: negative relationships and negative asymmetry in social networks in organizations', Academy of Management Review, 31 (3), 596-614.

Langrish, J., Gibbons, M., Evans, W. G., and Jevons, F. R. (1972) Wealth from Knowledge: A Study of Innovation in Industry, MacMillan, London.

Larson, A. (1992) 'Network dyads in entrepreneurial settings: a study of the governance of exchange relationships’, American Science Quarterly, 37 (1), 76-104.

Laursen, K. and Salter, A. (2006) 'Open for innovation: the role of openness in explaining innovation performance among U.K. manufacturing firms', Strategic Management Journal, 27 (2), 131-150.

Laursen, K., Reichstein, T., and Salter, A. (2011) 'Exploring the effect of geographical proximity and university quality on university-industry collaboration in the United Kingdom', Regional Studies, 45 (4), 507-523.

Laursen, K., Masciarelli, F., and Prencipe, A. (2012) 'Regions matter: how localized social capital affects innovation and external knowledge acquisition’, Organization Science 23 (1), 177-193.

Lavie, D. (2006) 'The competitive advantage of interconnected firms: an extension of the resource-based view', Academy of Management Review, 31 (3), 638-658.

Lawton Smith, H., Romeo, S., and Virahsawmy, M., (2012) 'Business and professional networks: scope and outcomes in Oxfordshire’, Environment and Planning A, 44 (8), 1801-1818.

Lechner, C. and Dowling, M. (2003) 'Firm networks: external relationships as sources for the growth and competitiveness of entrepreneurial firms', Entrepreneurship \& Regional Development, 15 (1), 1-26.

Lerner, J. and Merges, R. P. (1998) 'The control of technology alliances: an empirical analysis of the biotechnology industry', Journal of Industrial Economics, 46 (2), 125156.

Levine, S. S. (2005) The strength of Performative Ties: Three Essays on Knowledge, Social Networks, and Exchange, PhD dissertation, University of Pennsylvania, PA.

Lichtenthaler, U. (2005) 'External commercialization of knowledge: review and research agenda’, International Journal of Management Reviews, 7 (4), 231-255.

Lindell, M. K. and Whitney, D. J. (2001) 'Accounting for common method variance in crosssectional research designs', Journal of Applied Psychology, 86 (1), 114-121.

Lissoni, F. (2001) 'Knowledge codification and the geography of innovation: the case of Brescia mechanical cluster', Research Policy, 30 (9), 1479-1500.

Lorentzen, A. (2008) 'Knowledge networks in local and global space', Entrepreneurship and Regional Development, 20 (6), 533-545.

Mackun, P. and MacPherson, A. D. (1997) 'Externally-assisted product innovation in the manufacturing sector: the role of location, in-house R\&D and outside technical support', Regional Studies, 31 (7), 659-668.

Macpherson, A., and Holt, R. (2007) 'Knowledge, learning and small firm growth: a systematic review of the evidence', Research Policy 36 (2), 172-92.

Maggioni, M. and Uberti, T. E. (2009) 'Knowledge networks across Europe: which distance matters?', Annals of Regional Science, 43 (3), 691-720.

Malecki, E. J. (2007) 'Cities and regions competing in the global economy: knowledge and local development policies', Environment and Planning C: Government and Policy, 25 (3), 638-54. 
Mancinelli, S. and Mazzanti, M. (2009) 'Innovation, networking and complementarity: evidence on SME performances for a local economic system in North-Eastern Italy', Annals of Regional Science, 43 (3), 567-597.

March, J. G. (1991) 'Exploration and exploitation in organizational learning', Organization Science, 2 (1), 71-87.

Martin, R. and Sunley, P. (2007) 'Complexity thinking and evolutionary economic geography', Journal of Economic Geography, 7 (5), 573-601.

Mattes, J. (2012) 'Dimensions of proximity and knowledge bases: innovation between spatial and non-spatial factors', Regional Studies, 46 (8), 1085-1099.

McEvily, B. and Zaheer. A. (1999) 'Bridging ties: a source of firm heterogeneity in competitive capabilities’, Strategic Management Journal, 20 (12), 1133-1156.

McFadyen, M. A. and Cannella, A. A. (2004) 'Social capital and knowledge creation: diminishing returns of the number and strength of exchange relationships', Academy of Management Journal, 47 (5), 735-746.

Meagher, K. and Rogers. M. (2004) 'Network density and R\&D spillovers', Journal of Economic Behavior and Organization, 53 (2), 237-260.

Molina-Morales, F.X. and Expósito-Langa, M. (2012) 'The impact of cluster connectedness on firm innovation: R\&D effort and outcomes in the textile industry', Entrepreneurship and Regional Development, 24 (7-8), 685-704.

Monge, P. M., and Contractor, N. S. (2003) Theories of Communication Networks, New York: Oxford University Press.

Moreno, A. M. and Casillas, J. C. (2008) 'Entrepreneurial orientation and growth of SMEs: a causal model', Entrepreneurship Theory and Practice, 32 (3), 507-528.

Nonaka, I. and Takeuchi, H. (1995) The Knowledge-Creating Company: How Japanese Companies Create the Dynamics of Innovation, Oxford: Oxford University Press.

Office for National Statistics (2010) Business Demography 2010. (Accessed on 15 March 2012 from http://www.ons.gov.uk/ons/rel/bus-register/business-demography/2010/stb ---business-demography-2010.html).

Oliver, C. (1997) 'Sustainable competitive advantage: combining institutional and resourcebased views', Strategic Management Journal, 18 (9), 697-713.

Owen-Smith, J. and Powell, W. W. (2004) 'Knowledge networks as channels and conduits: the effects of spillovers in the Boston biotechnology community', Organizational Science, 15 (1), 5-21.

Palazzo, G. (2005) 'Postnational constellations of innovativeness: a cosmopolitan approach', Technology Analysis \& Strategic Management, 17 (1), 55-72.

Pittaway, L., Roberston, M., Munir, K. Denyer, D., and Neely, A. (2004) 'Networking and innovation: a systematic review of the evidence', International Journal of Management Reviews, 5/6 (3/4), 137-168.

Podsakoff, P. M., MacKenzie, S. B., Lee, J. Y., and Podsakoff, N. P. (2003) 'Common method biases in behavioral research: a critical review of the literature and recommended remedies', Journal of Applied Psychology, 88 (5), 879-903.

Podsakoff, P. M., MacKenzie, S. B., and Podsakoff, N. P. (2012) 'Sources of method bias in social science research and recommendations on how to control it', Annual Review of Psychology, 63, 539-569.

Podsakoff, P.M. and Organ, D. W. (1986) 'Self-reports in organizational research: problems and prospects', Journal of Management, 12 (2), 531-544.

Presutti, M., Boari, C., and Majocchi, A. (2013) 'Interorganizational geographical proximity and local start-ups' knowledge acquisition: a contingency approach', Entrepreneurship and Regional Development, 25 (5-6), 446-467. 
Quatraro, F. (2010) 'Knowledge coherence, variety and economic growth: manufacturing evidence from Italian regions’, Research Policy, 39 (10), 1289-1302.

Ritchie, F. and Evans, P. (2009) UK Company Statistics Reconciliation Project. Final Report, Department for Business, Enterprise and Regulatory Reform, London.

Roper, S., Du, J., and Love, J. H., (2008) 'Modelling the innovation value chain', Research Policy, 37 (6-7), 961-977.

Rothwell, R., Freeman, C., Horlsey, A., Jervis, V. T. P., Robertson, A. B., and Townsend, J., (1974) 'SAPPHO updated - project SAPPHO Phase II', Research Policy, 3 (3), 258291.

Sammarra, A. and Biggiero, L. (2008) 'Heterogeneity and specificity of inter-firm knowledge flows in innovation networks', Journal of Management Studies, 45 (4), 800-829.

Saxenian, A. (2005) 'From brain drain to brain circulation: transnational communities and regional upgrading in India and China', Studies in Comparative International Development, 40 (2), 35-61.

Schutjens, V. and Stam, E. (2003) 'The evolution and nature of young firm networks: a longitudinal perspective', Small Business Economics, 21 (2), 115-134.

Scott, A. (1995) 'The geographic foundations of industrial performance', Competition and Change, 1 (1), 51-66.

Shearmur, R. (2011) 'Innovation, regions and proximity: from neo-regionalism to spatial analysis’, Regional Studies, 45 (9), 1225-1243.

Simard, C. and West, J. (2006) 'Knowledge networks and the geographic locus of innovation', in Chesbrough, H., Vanhaverbeke, W., and West, J. (eds) Open Innovation: Researching a New Paradigm, Oxford University Press, Oxford, pp. 220240.

Sørensen, J. B. and Stuart, T. E. (2000) 'Aging, obsolescence, and organizational innovation', Administrative Science Quarterly, 45 (1), 81-112.

Stern, I. Dukerich, J. M. and Zajac, E. (2014) 'Unmixed signals: how reputation and status affect alliance formation’, Strategic Management Journal, 35 (4), 512-531.

Storper M. (2000) 'Globalizsation and knowledge flows: an industrial geographer's perspective', In Regions, Globalization, and the Knowledge-Based Economy, Dunning, J. H. (eds), Oxford: Oxford University Press.

Stuart, T. E. (2000) 'Interorganizational alliances and the performance of firms: a study of growth and innovation rates in a high-technology industry', Strategic Management Journal, 21 (8), 791-811.

Sturgeon, T. (2003) 'What really goes on in Silicon Valley? Spatial clustering and dispersal in modular production networks', Journal of Economic Geography, 3 (2), 199-225.

Teixeira, A. Santos, P., and Oliveira Brochado, A. (2006) 'Does proximity really matter in international R\&D cooperative projects?', Paper presented at the European Network on Industrial Policy (EUNIP) 9th International Conference, June 20-22, in Limerick, Ireland.

Ter Wal, A. and Boschma, R. (2011) 'Co-evolution of firms, industries and networks in space’, Regional Studies, 45 (7), 919-933.

Thomson, G. H. (1951) The Factorial Analysis of Human Ability. London University Press, London.

Thorpe, R., Holt, R., Macpherson, A., and Pittaway, L. (2005) 'Using knowledge within small and medium-sized firms: a systematic review of the evidence', International Journal of Management Reviews, 7 (4), 257-281.

Tomlinson, P. (2010) 'Co-operative ties and innovation: some new evidence for UK manufacturing', Research Policy, 39 (6), 762-775. 
Torré, A., (2008) 'On the role played by temporary geographical proximity in knowledge transmission', Regional Studies, 42 (6), 869-889.

Torré, A. and Rallet, A. (2005) 'Proximity and localisation', Regional Studies, 39 (1), 47-59.

Utterback, J. M. and Abernathy, W. J. (1975) 'A dynamic model of process and product innovation', Omega, 3 (6), 639-656.

van Geenhuizen, M. (2008) 'Knowledge networks of young innovators in the urban economy: biotechnology as a case study', Entrepreneurship \& Regional Development, 20 (2), 161-183.

Vanhaverbeke, W., (2006) 'The inter-organizational context of open innovation', In Chesbrough, H., Vanhaverbeke, W., and West, J. (eds) Open Innovation: Researching a New Paradigm, Oxford: Oxford University Press, pp. 205-219.

Werker, C. and Athreye, S. (2004) 'Marshall's disciples: Knowledge and innovation driving regional economic development and growth', Journal of Evolutionary Economics, 14(5), 505-523.

Westlund, H. and Bolton, R. (2003) 'Local social capital and entrepreneurship', Small Business Economics, 21 (1) 77-113.

Wiklund, J. and Shepherd, D. (2003) 'Knowledge-based resources, entrepreneurial orientation, and the performance of small and medium-sized businesses', Strategic Management Journal, 24 (13), 1307-1314.

Withers, M. C., Drnevich, P. L., and Marino, L. (2011) 'Doing more with less: the disordinal implications of firm age for leveraging capabilities for innovation activity', Journal of Small Business Management, 49 (4), 515-536.

Wolfe, D. and Gertler, M. (2004) 'Clusters from the inside and out: local dynamics and global linkages’, Urban Studies, 41 (5/6), 1071-1093.

Yli-Renko, H. Autio, E. and Sapienza, H. J. (2001) 'Social capital, knowledge acquisition, and knowledge exploitation in young technology-based firms', Strategic Management Journal , 22 (6/7), 587-613.

Zaheer, A. and Bell, G. (2005) 'Benefiting from network position: firm capabilities, structural holes, and performance', Strategic Management Journal, 26 (9), 809-825.

Zahra, S. A. and George, G. (2002) 'Absorptive capacity: a review, reconceptualization, and extension', Academy of Management Review, 27 (2), 185-203.

Zhang, X. and Chen, R. (2008) 'Examining the mechanism of the value co-creation with customers', International Journal of Production Economics, 116 (2), 242-250. 
Figure 1: Firm Age and Turnover Growth

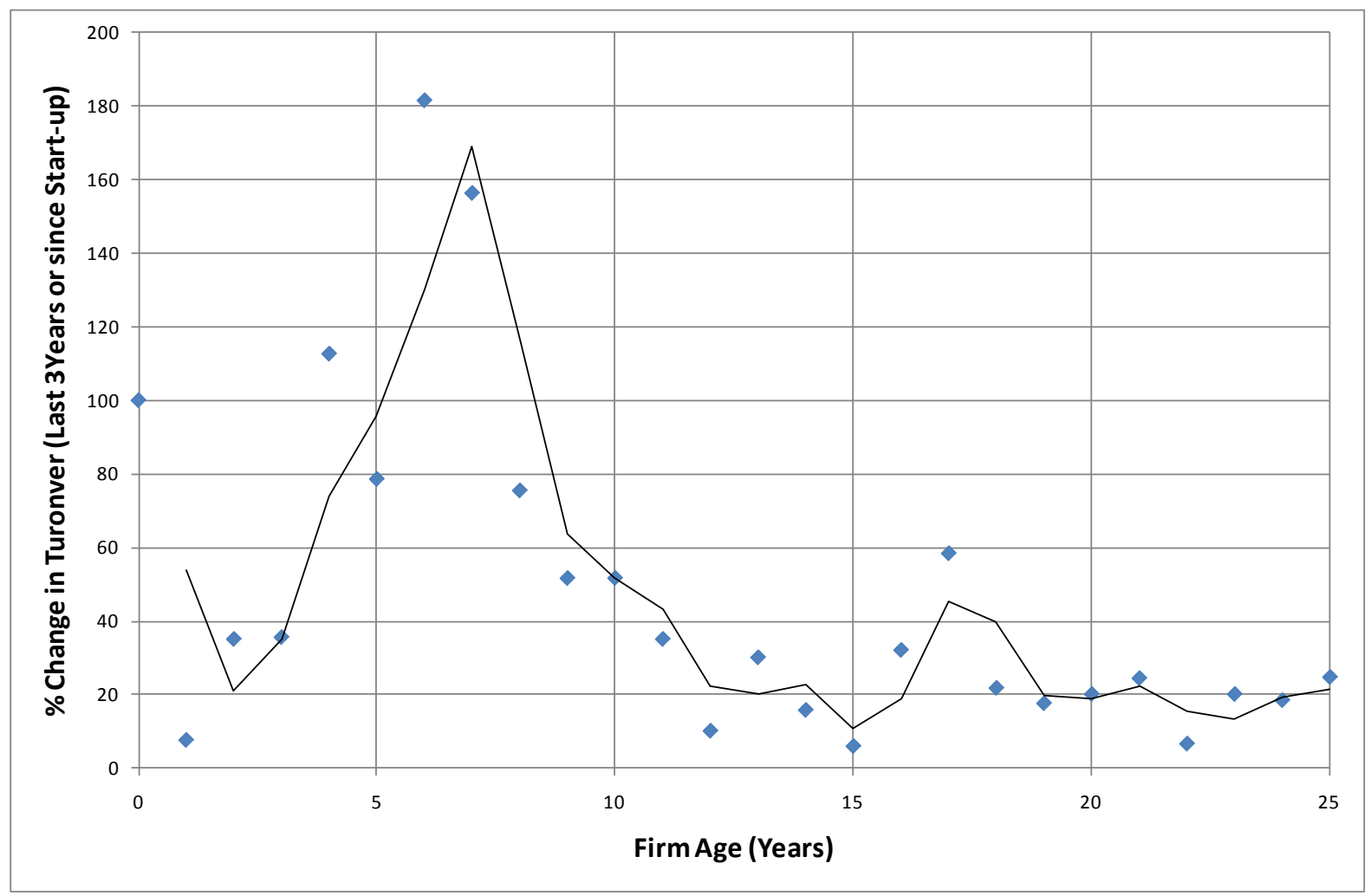


Figure 2: Firm Age and Rates of Innovation (number introduced in the 3 preceding years or since start-up)

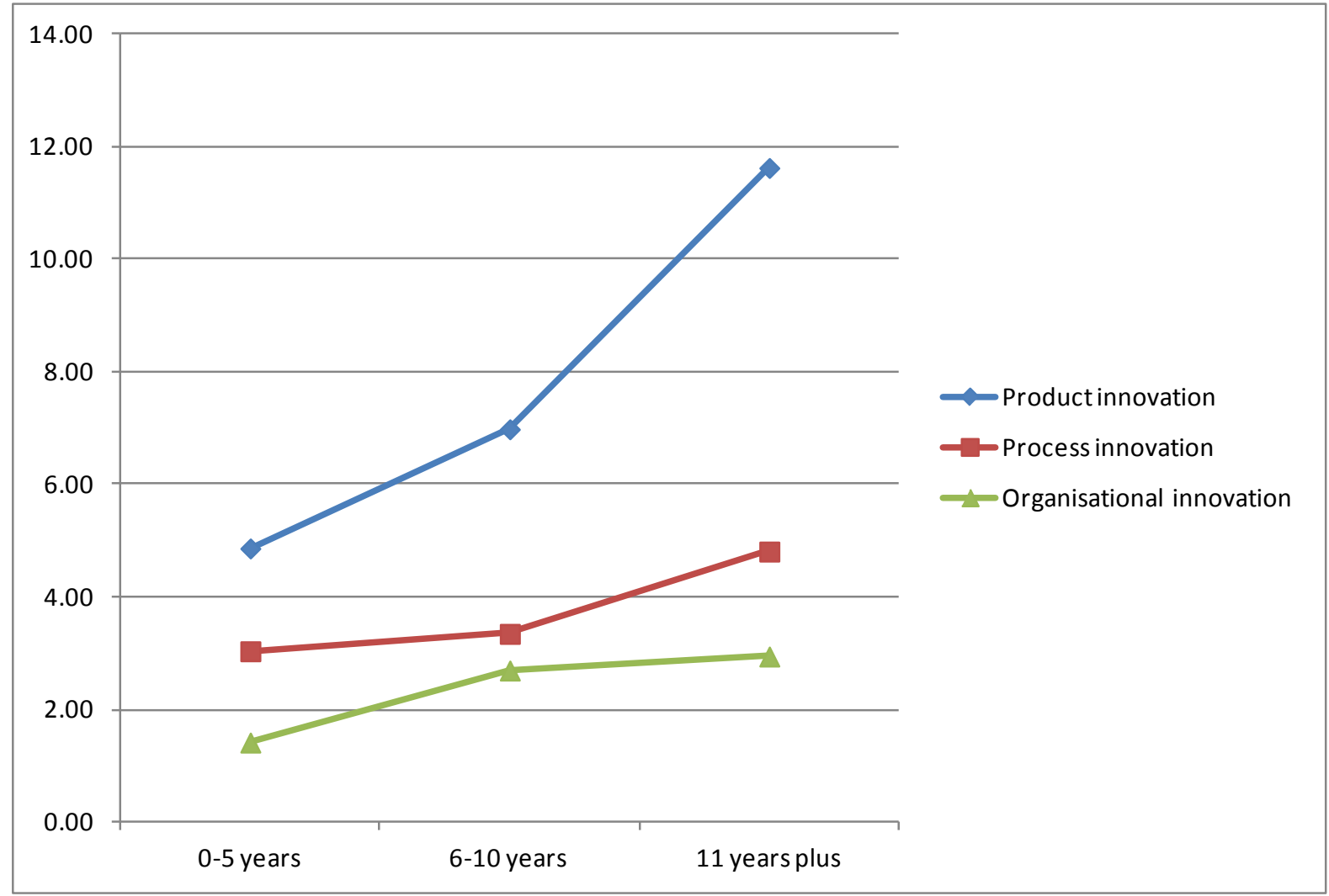


Figure 3: Firm Age and the Frequency of Accessing Knowledge by Geographic Location of Source $(0=$ Never; $10=$ Very Often $)$

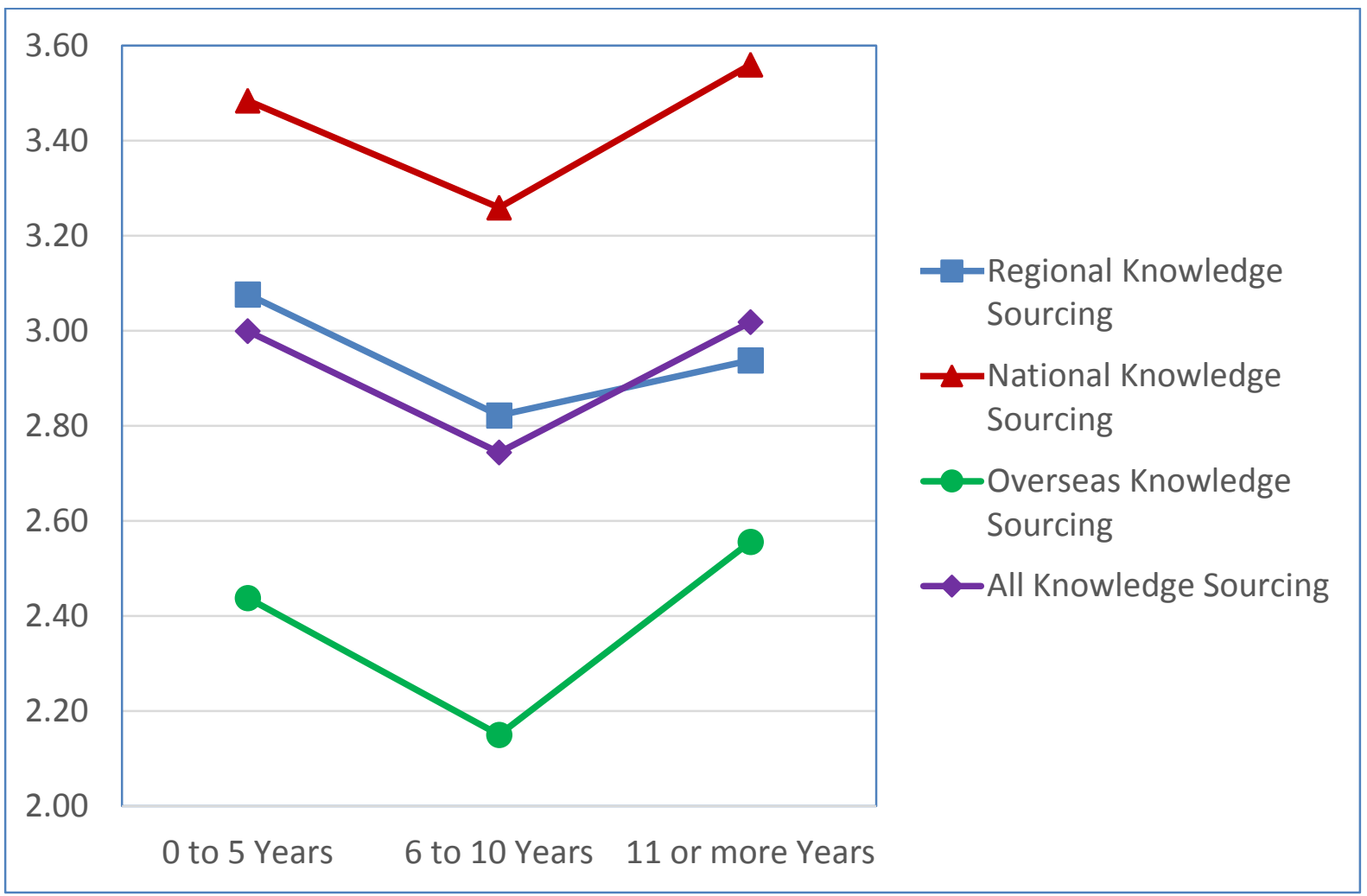


Figure 4: Firm Age and the Frequency of Accessing DUI Knowledge for Innovation

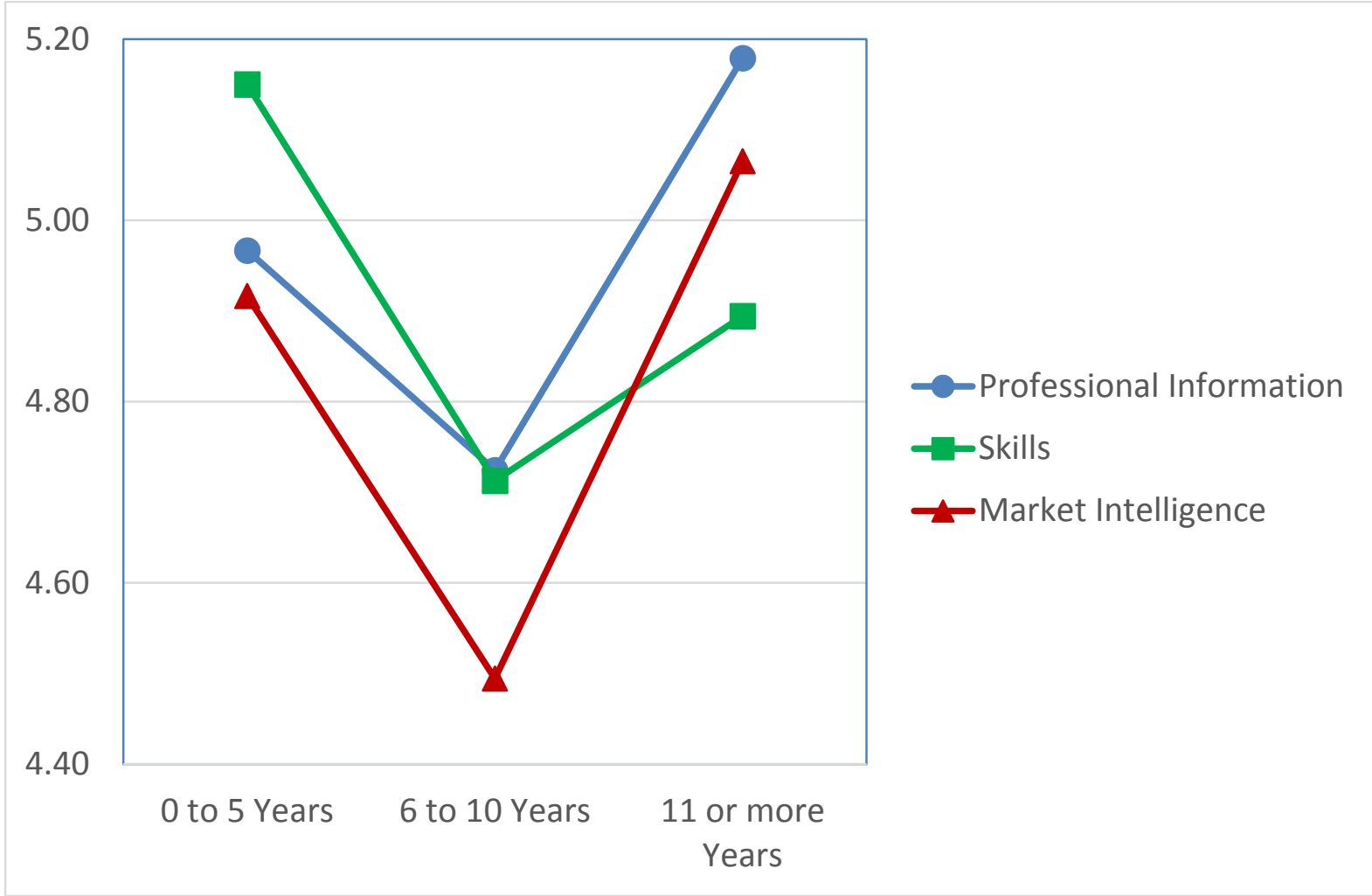


Table 1: Breakdown of the Firm Sample and Responding Firms by Size, Age, Sector and Region (\% of Total Sample/Responses)

\begin{tabular}{|c|c|c|c|c|c|c|c|c|c|c|c|}
\hline Size & Sample & Respondents & Age & Sample & Respondents & Sector & Sample & Respondents & Region & Sample & Respondents \\
\hline Small & $69.2 \%$ & $74.4 \%$ & $\begin{array}{l}\text { Mean } \\
\text { Age }\end{array}$ & $20.5 \%$ & $20.2 \%$ & $\begin{array}{l}\text { High Technology } \\
\text { Manufacturing }\end{array}$ & $2.1 \%$ & $13.8 \%$ & East Midlands & $5.4 \%$ & $5.2 \%$ \\
\hline Medium & $20.7 \%$ & $19.3 \%$ & $\begin{array}{l}\text { Median } \\
\text { Age }\end{array}$ & $14.5 \%$ & $14.5 \%$ & $\begin{array}{l}\text { Medium-High } \\
\text { Technology } \\
\text { Manufacturing }\end{array}$ & $8.4 \%$ & $8.5 \%$ & $\begin{array}{l}\text { East of } \\
\text { England }\end{array}$ & $13.0 \%$ & $13.8 \%$ \\
\hline \multirow[t]{10}{*}{ Large } & $10.1 \%$ & $6.2 \%$ & $\begin{array}{l}\text { Std. } \\
\text { Deviation }\end{array}$ & $17.9 \%$ & $16.7 \%$ & $\begin{array}{l}\text { Medium-Low } \\
\text { Technology } \\
\text { Manufacturing }\end{array}$ & $10.7 \%$ & $7.9 \%$ & London & $12.7 \%$ & $10.2 \%$ \\
\hline & & & & & & $\begin{array}{l}\text { Low Technology } \\
\text { Manufacturing }\end{array}$ & $5.9 \%$ & $5.2 \%$ & North East & $3.3 \%$ & $2.6 \%$ \\
\hline & & & & & & $\begin{array}{l}\text { Knowledge-Intensive } \\
\text { Services }\end{array}$ & $67.1 \%$ & $56.1 \%$ & $\begin{array}{l}\text { Northern } \\
\text { Ireland }\end{array}$ & $2.0 \%$ & $2.0 \%$ \\
\hline & & & & & & $\begin{array}{l}\text { Low Knowledge- } \\
\text { Intensive Services }\end{array}$ & $1.7 \%$ & $5.2 \%$ & North West & $9.6 \%$ & $11.8 \%$ \\
\hline & & & & & & $\begin{array}{l}\text { Other Non-Technology } \\
\text { Services }\end{array}$ & $4.1 \%$ & $3.3 \%$ & Scotland & $8.2 \%$ & $5.2 \%$ \\
\hline & & & & & & & & & South East & $17.1 \%$ & $15.7 \%$ \\
\hline & & & & & & & & & South West & $6.7 \%$ & $8.5 \%$ \\
\hline & & & & & & & & & Wales & $3.1 \%$ & $4.3 \%$ \\
\hline & & & & & & & & & $\begin{array}{l}\text { West } \\
\text { Midlands }\end{array}$ & $11.8 \%$ & $12.1 \%$ \\
\hline & & & & & & & & & $\begin{array}{l}\text { Yorkshire and } \\
\text { the Humber }\end{array}$ & $7.1 \%$ & $8.5 \%$ \\
\hline
\end{tabular}


Table 2: Factor Analysis: Rotated Factor Matrix

\begin{tabular}{|c|c|c|c|c|c|c|}
\hline & $\begin{array}{l}\text { Within a } \\
\text { firm’s own } \\
\text { region } \\
\text { 'Firm based' } \\
\text { knowledge } \\
\text { sources }\end{array}$ & $\begin{array}{l}\text { Within a } \\
\text { firm's own } \\
\text { region } \\
\text { 'Non-firm } \\
\text { based' } \\
\text { knowledge } \\
\text { sources }\end{array}$ & $\begin{array}{l}\text { Elsewhere in } \\
\text { the UK } \\
\text { 'Firm based' } \\
\text { knowledge } \\
\text { sources }\end{array}$ & $\begin{array}{l}\text { Elsewhere in } \\
\text { the UK } \\
\text { 'Non-firm } \\
\text { based' } \\
\text { knowledge } \\
\text { sources }\end{array}$ & $\begin{array}{c}\text { Overseas } \\
\text { 'Firm based' } \\
\text { knowledge } \\
\text { sources }\end{array}$ & $\begin{array}{c}\text { Overseas } \\
\text { 'Non-firm } \\
\text { based' } \\
\text { knowledge } \\
\text { sources }\end{array}$ \\
\hline Suppliers of equipment, materials, services, and software & 0.527 & 0.178 & 0.552 & 0.217 & 0.528 & 0.206 \\
\hline Clients and customers & 0.723 & 0.112 & 0.589 & 0.166 & 0.760 & 0.242 \\
\hline Competitors and other businesses in the firm's industry & 0.706 & 0.162 & 0.672 & 0.060 & 0.728 & 0.179 \\
\hline Commercial labs and private R\&D institutes & 0.205 & 0.471 & 0.109 & 0.528 & 0.331 & 0.605 \\
\hline Universities and other higher education institutes & 0.149 & 0.475 & 0.174 & 0.569 & 0.328 & 0.584 \\
\hline Government and public research institutes & 0.319 & 0.478 & 0.240 & 0.361 & 0.172 & 0.632 \\
\hline Conferences, trade fairs, and exhibitions & 0.575 & 0.401 & 0.514 & 0.206 & 0.647 & 0.315 \\
\hline
\end{tabular}


Table 3: Descriptive Statistics, $N=299$

\begin{tabular}{lcc}
\hline & Mean & $\begin{array}{c}\text { Standard } \\
\text { deviation }\end{array}$ \\
\hline Firm-based knowledge sources within a firm's region & 0.00 & 0.83 \\
Non-firm based knowledge sources within a firm's region & 0.00 & 0.67 \\
Firm-based knowledge sources elsewhere in the UK & 0.00 & 0.80 \\
Non-firm based knowledge sources elsewhere in the UK & 0.00 & 0.68 \\
Firm-based knowledge sources outside the UK & 0.00 & 0.85 \\
Non-firm based knowledge sources outside the UK & 0.00 & 0.76 \\
Firm age: 6 to 10 years (binary) & 0.28 & 0.45 \\
Firm age: over 10 years (binary) & 0.52 & 0.50 \\
Natural log employees & 2.91 & 1.49 \\
Subsidiary (binary) & 0.29 & 0.45 \\
Absorptive capacity & 1.75 & 0.70 \\
\hline
\end{tabular}

Note: Sector dummies and region dummies are not reported. 
Table 4: Firm Age and the Frequency of Accessing Knowledge by Source $(0=$ Never; $10=$ Very Often)

\begin{tabular}{l|ccc|c}
\hline Source & $0-5$ years & $6-10$ years & 11 years plus & Average All \\
\hline Suppliers & 4.78 & 4.28 & 4.71 & 4.59 \\
\hline Customers & 4.78 & 4.79 & 4.91 & 4.85 \\
\hline Competitors & 3.31 & 3.04 & 3.16 & 3.15 \\
\hline Consultants & 2.11 & 1.89 & 2.23 & 2.10 \\
\hline Commercial Labs & 1.08 & 0.84 & 1.30 & 1.10 \\
\hline Universities & 2.96 & 2.92 & 2.60 & 2.78 \\
\hline $\begin{array}{l}\text { Government Research } \\
\text { Institutes }\end{array}$ & 1.62 & 1.47 & 1.75 & 1.63 \\
\hline Conferences/Trade Fairs & 3.65 & 3.32 & 3.71 & 3.57 \\
\hline
\end{tabular}


Table 5: OLS Estimation of Knowledge Sourcing from Firm Based Sources

\begin{tabular}{lccc}
\hline \multicolumn{4}{c}{ Dependent variable: knowledge sourcing from firm based sources } \\
\hline Location of knowledge sources & $\begin{array}{c}\text { Within a firm's } \\
\text { own region }\end{array}$ & $\begin{array}{c}\text { Elsewhere } \\
\text { in the UK }\end{array}$ & Overseas \\
\hline Firm age: 6 to 10 years (binary) & -0.021 & -0.142 & -0.162 \\
& $(0.137)$ & $(0.139)$ & $(0.134)$ \\
Firm age: over 10 years (binary) & 0.059 & -0.149 & $-0.270^{* *}$ \\
& $(0.137)$ & $(0.140)$ & $(0.134)$ \\
Natural log employees & 0.070 & $0.116^{* * *}$ & $0.133^{* * *}$ \\
& $(0.041)$ & $(0.041)$ & $(0.040)$ \\
Subsidiary (binary) & -0.037 & 0.047 & $0.486^{* * *}$ \\
& $(0.118)$ & $(0.120)$ & $(0.115)$ \\
Absorptive capacity & 0.057 & $-0.126^{*}$ & $-0.181^{* * *}$ \\
Constant & $(0.068)$ & $(0.069)$ & $(0.066)$ \\
& $1.232^{* *}$ & $1.434^{* *}$ & -0.313 \\
Sector dummies & $(0.618)$ & $(0.630)$ & $(0.605)$ \\
Region dummies & Yes (18 sectors) & Yes (18 sectors) & Yes (18 sectors) \\
Observations & Yes (12 regions) & Yes (12 regions) & Yes (12 regions) \\
$R^{2}$ & 299 & 299 & 299 \\
\hline
\end{tabular}

Notes: $*, * *$, and $* * *$ denote significance at the 10,5 , and $1 \%$ level respectively. Standard errors are given in parentheses. The null hypothesis of homoscedasticity is not rejected in Breusch-Pagan/ Cook-Weisberg tests for each of the three geographical levels. 
Table 6: Robust OLS Estimation of Knowledge Sourcing from Non-Firm Based Sources

\begin{tabular}{lccc}
\hline \multicolumn{4}{c}{ Dependent variable: knowledge sourcing from non-firm based sources } \\
\hline Location of knowledge sources & $\begin{array}{c}\text { Within a firm's } \\
\text { own region }\end{array}$ & $\begin{array}{c}\text { Elsewhere } \\
\text { in the UK }\end{array}$ & Overseas \\
\hline Firm age: 6 to 10 years (binary) & $-0.286^{* *}$ & -0.001 & 0.091 \\
& $(0.128)$ & $(0.121)$ & $(0.111)$ \\
Firm age: over 10 years (binary) & -0.188 & 0.076 & 0.098 \\
& $(0.123)$ & $(0.116)$ & $(0.129)$ \\
Natural log employees & 0.037 & 0.054 & $0.096^{*}$ \\
Subsidiary (binary) & $(0.029)$ & $(0.033)$ & $(0.050)$ \\
& 0.053 & 0.171 & $0.194^{*}$ \\
Absorptive capacity & $(0.100)$ & $(0.106)$ & $(0.112)$ \\
Constant & -0.056 & -0.041 & 0.080 \\
& $(0.061)$ & $(0.057)$ & $(0.055)$ \\
\hline Sector dummies & 1.397 & 0.822 & $-1.153^{* * *}$ \\
Region dummies & $(1.201)$ & $(1.069)$ & $(0.334)$ \\
Observations & Yes (18 sectors) & Yes (18 sectors) & Yes (18 sectors) \\
$R^{2}$ & Yes (12 regions) & Yes (12 regions) & Yes (12 regions) \\
\hline
\end{tabular}

Notes: *,**, and $* * *$ denote significance at the 10,5 , and $1 \%$ level respectively. Standard errors are given in parentheses. The null hypothesis of homoscedasticity is rejected in Breusch-Pagan/ CookWeisberg tests at the $1 \%$ level for each of the three geographical levels. 